\title{
Nutritional importance of minor dietary sources for leaping grey mullet Liza saliens (Mugilidae) during settlement: insights from fatty acid $\delta^{13} \mathrm{C}$ analysis
}

\author{
Apostolos-Manuel Koussoroplis ${ }^{1,2, *}$, Alexandre Bec ${ }^{1,2}$, Marie-Elodie Perga ${ }^{3}$, \\ Emmanuil Koutrakis ${ }^{4}$, Christian Desvilettes ${ }^{1,2}$, Gilles Bourdier ${ }^{1,2}$ \\ ${ }^{1}$ Clermont Université, Université Blaise Pascal, Laboratoire Microorganismes: Génome et Environnement (LMGE), BP 10448, \\ 63000 Clermont-Ferrand, France \\ ${ }^{2}$ National Center for Scientific Research (CNRS), LMGE, UMR 6023, 63173, Aubière, France \\ ${ }^{3}$ National Institute for Agricultural Research (INRA), Station d'Hydrobiologie Lacustre, BP 511, 74203 Thonon-les-Bains, France \\ ${ }^{4}$ National Agricultural Research Foundation (NAGREF), Fisheries Research Institute, Department of Inland Waters and \\ Lagoons, 64007 Nea Peramos, Greece
}

\begin{abstract}
The present case study combined fatty acid analysis and compound-specific carbon isotopic analysis of fatty acids in order to trace changes in dietary sources of essential fatty acids during settlement of the estuarine fish Liza saliens (Mugilidae) in its lagoon nursery. Compositional and isotopic shifts in neutral and polar lipid-derived fatty acids were analysed separately, as these 2 lipid classes are thought to integrate dietary isotopic signals differently. An increase of $5 \%$ in the $\delta^{13} \mathrm{C}$ of many fatty acids in settled fish indicated that they had shifted from planktonic to benthic resources during settlement. However, the sharp decrease in the proportion of 22:6 $\omega 3$ in settled fish and the fact that this specific fatty acid kept a planktonic $\delta^{13} \mathrm{C}$ signature revealed that benthic resources could not

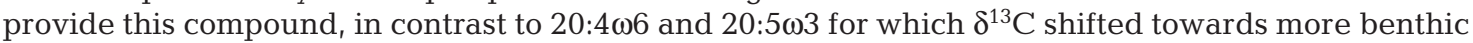
values. Consequently, although the production of settled fish was essentially supported by benthic dietary sources, as confirmed by biomarker results, minor reliance on planktonic dietary sources was required to provide fish with 22:6 $\omega 3$. The lag between the increase in $\delta^{13} \mathrm{C}$ in fatty acids derived from neutral and polar lipids suggested that neutral lipid fatty acids integrated the dietary isotopic signal faster. These contrasting dynamics highlight the importance of analyzing lipid classes separately when fast dietary shifts are expected, and could be used to obtain dietary information over different time scales.
\end{abstract}

KEY WORDS: Compound-specific isotope analysis · Neutral lipids · Polar lipids · Fatty acids · Lagoons · Food webs

Resale or republication not permitted without written consent of the publisher

\section{INTRODUCTION}

Many organisms migrate during their lives in order to find environmental conditions which maximize fitness (Albon \& Langvatn 1992, Dini \& Carpenter 1992, Rittenhouse et al. 2009, Wysujack et al. 2009). These movements between different environments and thus different food webs imply dietary shifts and behav- ioural change. Migration-induced dietary switches often occur during crucial steps in the organism's life cycle (reproduction, larval settlement, metamorphosis) in which metabolic needs are high. Therefore, during these events, both food quantity and quality may be determinant for the fitness of individuals and thus the ecological success of populations (Vanni \& Lampert 1992, Gibson 1994, Bell \& Sargent 1996). 
Carbon isotope ratio analysis is a powerful tool to study trophic linkage within ecosystems and dietary shifts in animals, enabling major carbon flows to be traced in food webs (McConnaughey \& McRoy 1979, Vander Zanden et al. 1999). However, bulk carbon isotope analysis provides information on dietary sources most significantly contributing to consumers' secondary production (Perga \& Gerdeaux 2005), but not on the nutritional quality of the assimilated food. For example, in the case of complex environments such as estuarine ecosystems, with multiple primary producers and organic matter inputs, the proportion and nutritional quality of the various carbon sources may not be homogeneously distributed between sources (Alfaro et al. 2006, Richoux \& Froneman 2008). Hence, a minor dietary source, the carbon of which does not support significant secondary production, might play a significant functional role as a supplier of nutritionally important compounds. Thus, in identifying only the quantitatively important organic matter sources, classical stable isotope analysis may have largely underestimated the functional importance of minor dietary sources. The importance of the nutritional quality of food is widely accepted, and compounds such as essential fatty acids (FAs) $(20: 4 \omega 6,20: 5 \omega 3,22: 6 \omega 3)$ are known to play a key role in many physiological processes (Arts 1998, Olsen 1998, Arts et al. 2001). Deficiencies in these compounds have a direct impact on the fitness of young fish and may affect recruitment into adult populations (Bell \& Sargent 1996, Adams 1998, Olsen 1998). Moreover, essential FAs cannot be synthesized at sufficient rates by most animals and have to be provided by food (Bec et al. 2006). Therefore, it is crucial to verify the quality of assimilated dietary sources in order to achieve a more precise understanding of the dietary factors underlying population dynamics.

Some FAs are specific to certain dietary sources (bacteria, diatoms, dinoflagellates, macroalgae, vascular plants) and can be transferred to higher trophic levels and thus be used as biomarkers (Viso \& Marty 1993, Napolitano 1998, Dalsgaard et al. 2003, Koussoroplis et al. 2008, Desvilettes \& Bec 2009). Nevertheless, essential FAs are not always specific, as they can be simultaneously present in more than one source, hence limiting their value as biomarkers. However, by characterizing these compounds isotopically (compoundspecific isotopic analysis [CSIA]), it is possible to determine whether all essential FAs have common or distinct sources, and also to obtain specific information on their origins (Murphy \& Abrajano 1994, Pond et al. 1997a,b, Rieley et al. 1999, Chamberlain et al. 2004, Van den Meersche et al. 2009). Moreover, the rapid isotopic turnover of FAs compared to other biochemical fractions makes analysis of their $\delta^{13} \mathrm{C}$ a very reac- tive proxy for fast dietary change (Meier-Augenstein 2002, Lau et al. 2009).

Most marine fish store their lipids in the form of neutral lipids (NLs; mainly triacylglycerols), whereas cellmembrane lipids are mostly in the form of polar lipids (PLs; mainly phospholipids) (Dalsgaard et al. 2003). Dietary lipids are hydrolysed in the gut and the liberated FAs are absorbed into epithelial cells where they are re-esterified, often without any transformation into NLs or PLs, and transported to tissue (Sargent et al. 1989, 1993, Dalsgaard et al. 2003). Because of their distinct physiological roles, the different lipid classes are thought to have different turnover rates (Veefkind 1997). Although little studied to date, contrasting dynamics between these 2 lipid classes could affect the integration of the dietary FA $\delta^{13} \mathrm{C}$ signal and thus the interpretation of FA isotope data.

Leaping grey mullet Liza saliens (Pisces, Mugilidae) is a common Mediterranean estuarine fish species with a life-cycle involving migration from offshore to estuarine areas. Reproduction takes place between late spring and late fall in offshore areas (Koutrakis 1994). Planktonic eggs hatch offshore, and larvae measure approximately 1.7 to $2 \mathrm{~mm}$ total length (TL). At $4 \mathrm{~mm}$ TL, larvae with resorbed vesicles start feeding on marine plankton. In northeast Greece, L. saliens migration towards coastal lagoons occurs at 10 to $15 \mathrm{~mm}$ TL, between early summer and late fall (Koutrakis 1994, 2004, Koutrakis et al. 2005). Once in their coastal nursery, post-larvae progressively switch from zooplanktonic prey to a benthic omnivore diet (AlbertiniBerhaut 1980).

We hypothesized that changes in origin of essential FAs as a result of dietary switch would be isotopically reflected in fish FAs, and that such changes would be integrated differently in NLs and PLs. We therefore analysed the carbon isotope composition of FAs derived from the NLs and PLs of Liza saliens in order to (1) assess the dietary sources of essential FAs for L. saliens in the lagoon nursery, and (2) study the isotope dynamics of FAs in PLs and NLs.

\section{MATERIALS AND METHODS}

Study site. The study was conducted in the Vassova Lagoon (Fig. 1), a small $\left(0.7 \mathrm{~km}^{2}\right)$ shallow (mean depth $=1 \mathrm{~m}$ ) eutrophicated brackish lagoon. The lagoon is segmented into a large central shallow basin (mean depth $=0.5 \mathrm{~m}$ ) and artificial $3 \mathrm{~m}$ deep wintering and stocking channels. The connection to the adjacent sea is via a single narrow (max. width $=30 \mathrm{~m}$ ) and shallow (mean depth $=0.8 \mathrm{~m}$ ) channel, classifying the lagoon as choked (Kjerfve 1994). Freshwater and nutrient input occurs through precipitation and a number of 


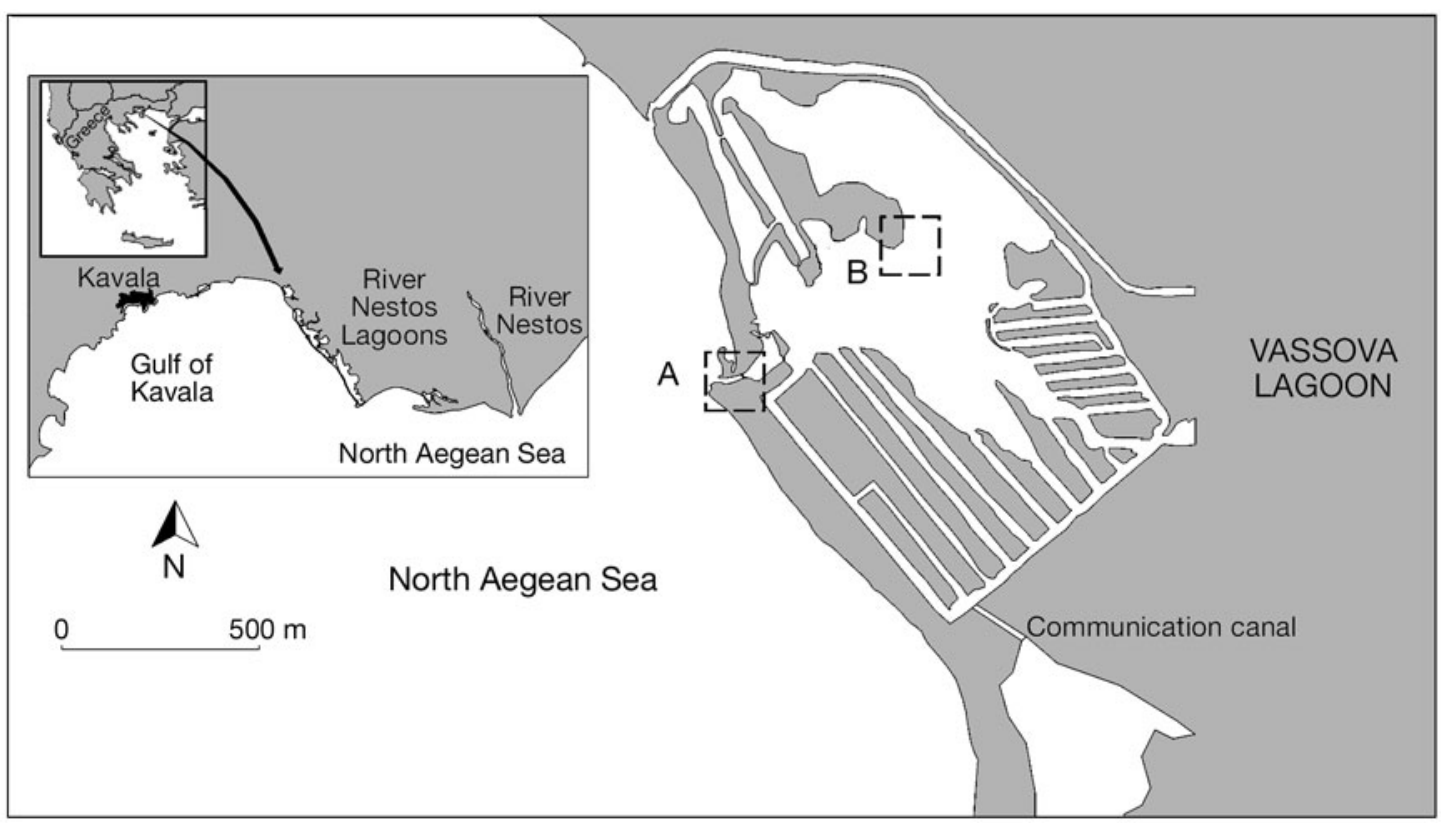

Fig. 1. Vassova Lagoon and the River Nestos Delta lagoons (Greece), reproduced from Tsihrintzis et al. (2007). Sampling sites A and $\mathrm{B}$ are indicated with dashed boxes

small inlets connecting the northern part of the lagoon to adjacent drainage channels (Orfanidis et al. 2005). During the study period, temperature and salinity in the central basin ranged from 25 to $29^{\circ} \mathrm{C}$ and 15 to $25 \mathrm{psu}$, respectively. Opportunistic macroalgae (Gracilaria sp., Ulva sp.) totally cover the central basin and annual chlorophyll a (chl a) means are very low (1.41 $\mathrm{\mu g} \mathrm{l}^{-1}$ ) (Orfanidis et al. 2005).

Sampling. Fish (10 to $50 \mathrm{~mm}$ TL) were sampled every 2 wk from June to September 2007 by a handtrawled seine net (12 $\mathrm{m}$ long, $1.5 \mathrm{~m}$ high, $2 \mathrm{~mm}$ mesh) in the lagoon's entrance (Site A) and main basin (Site B). Fish were ice-shocked and immediately transported to the laboratory, where TL was measured to the closest $0.5 \mathrm{~mm}$, and stored at $-80^{\circ} \mathrm{C}$ before analysis. During the sampling period, more than 200 Liza saliens juveniles were captured, including 87 reserved for stomach contents analysis and 15 for FA and CSIA analysis. Individuals for FA and CSIA analysis were selected to give the closest possible representation of a cohort, and arbitrarily separated into 5 size class intervals $(10-15 \mathrm{~mm}, 15-20 \mathrm{~mm}, 20-30 \mathrm{~mm}$, 30-40 mm, and 40-50 $\mathrm{mm}$ TL). Three young adult fish (>200 mm TL) were also sampled in the fish-trap installations of the lagoon and were used as reference for a dietarily and spatially stabilized state.

To estimate the range of $\delta^{13} \mathrm{C}$ values for the various Liza saliens food sources, zooplankton, epibenthic invertebrates, sediment and dominant benthic macroalgae were sampled. As density was too low in the central basin, zooplankton was sampled only in the lagoon entrance, by horizontal hauls with a hand-trawled bongo net (100 $\mu \mathrm{m}$ mesh) fitted to a floater. Epibenthic invertebrates (benthic harpacticoids and amphipods) were collected by a hand-towed net (300 $\mu \mathrm{m}$ mesh). Replicate samples $(\mathrm{n}=4)$ of the first centimetre of sediment from the central basin were collected using hand-corers (5 $\mathrm{cm}$ internal diameter). Collected surface sediment was resuspended in artificial sterile seawater and carefully sieved on a $64 \mu \mathrm{m}$ Nitex mesh to eliminate meiofauna and large debris, and filtered by precombusted GF/F glass fibre filters (Whatman). The dominant benthic macroalgae (Gracilaria sp.: $\mathrm{n}=2$; Ulva sp.: $\mathrm{n}=2$ ) were hand-picked from the central basin, scraped to eliminate epifauna and epiflora, and rinsed with sterile artificial seawater. Sample information is summarized in Table 1.

Stomach contents analysis. In order to determine the size at which fish settled (i.e. shifted towards benthic foraging), stomach contents of 87 Liza saliens (10-50 mm TL) were examined under a binocular microscope. Diet items were grouped into 4 categories: zooplankton (calanoid and cyclopoid copepods, nauplii), epibenthic prey (harpacticoid copepods, bivalve post-larvae, amphipods), sand/detritus and macroalgal material (debris of macroalgal tissue). The frequency of occurrence and mean numerical abundance of these food categories were measured, where frequency of occurrence is the percentage of stomachs in which an item was present, and mean numerical abundance is the number of individuals of a food category divided by the total number of individuals, expressed as a percentage, after pooling the stomach contents of all fish by size class. 
FA and FA isotope analysis. Lipids were extracted from triplicate samples of individual muscle tissue in a chloroform/methanol mixture $(2: 1 \mathrm{v} / \mathrm{v})$ (Folch et al. 1957). Total lipid extracts were fractionated with Phenomenex ${ }^{\circledR}$ Strata-NH2 ${ }^{\mathrm{TM}}$ solid phase extraction columns into NL (acyl-glycerols) and PL and eluted in chloroform/2-propanol (2:1 v/v) and methanol, respectively. FAs from NL and PL fractions were converted into FA methyl esters (FAMEs) by acid-catalyzed transesterification according to a modified protocol from Christie (1982) $\left(2 \% \mathrm{H}_{2} \mathrm{SO}_{4}\right.$ in methanol at $75^{\circ} \mathrm{C}$ for $2 \mathrm{~h}$ ). FA analysis was carried out on an Agilent 6850 gas chromatograph equipped with a J\&W DB-WAX capillary column $(30 \mathrm{~m}$ length $\times 0.250 \mathrm{~mm}$ internal diameter [ID] $\times 0.25 \mu \mathrm{m}$ film thickness) and flame ionization detector $\left(240^{\circ} \mathrm{C}\right.$ ) (split ratio 1:10; inlet temperature $240^{\circ} \mathrm{C}_{i}$ carrier gas, helium; oven temperature rise from 150 to $240^{\circ} \mathrm{C}$ at $3^{\circ} \mathrm{C} \mathrm{min}^{-1}$ with $15 \mathrm{~min}$ hold). Individual FAMEs were identified by comparing retention times with Supelco $^{\circledast}$ and laboratory standards. For FAME quantification, 2 internal standards (13:0 and 23:0, added prior to methylation) were used. Extracted sample FAMEs were analysed at the UC Davis Stable Isotope Facility for CSIA with a gas chromatography (GC)-combustion-isotope ratio mass spectrometer (IRMS) system: a Trace GC Ultra (Thermo Electron) was interfaced with a Finnigan Delta Plus IRMS (Thermo Electron) and installed with a BPX70 column (30.0 m length, $0.25 \mathrm{~mm}$ ID, $0.25 \mu \mathrm{m}$ film thickness; SGE Analytical Science). Samples were injected in splitless mode (inlet temperature $260^{\circ} \mathrm{C}_{i}$ carrier gas, helium; constant flow rate of $0.8 \mathrm{ml} \mathrm{min}^{-1}$; oven temperature rise from 100 to $190^{\circ} \mathrm{C}$ at $4^{\circ} \mathrm{C} \mathrm{min}^{-1}$ with

Table 1. Sample information, including sample type, date, location and subsequent analysis treatment. For site locations, see Fig. 1. TL: total length; FA: fatty acid

\begin{tabular}{|c|c|c|c|c|}
\hline Sample type & Collection date & Site & Treatment & $\mathrm{N}$ \\
\hline \multicolumn{5}{|l|}{ Liza saliens } \\
\hline $10-50 \mathrm{~mm} \mathrm{TL}$ & Jun-Sep 2007 & A, B & $\begin{array}{c}\text { Stomach contents } \\
\text { analysis }\end{array}$ & 87 \\
\hline $10-15 \mathrm{~mm}$ TL & 19 Jun 2007 & $\mathrm{~A}$ & $\begin{array}{c}\text { FA analysis, FA } \delta^{13} \mathrm{C} \\
\text { analysis }\end{array}$ & 3 \\
\hline $15-20 \mathrm{~mm}$ TL & 26 Jun 2007 & $\mathrm{~A}$ & & 3 \\
\hline $20-30 \mathrm{~mm}$ TL & 6 Aug 2007 & $\mathrm{~B}$ & & 3 \\
\hline $30-40 \mathrm{~mm}$ TL & 21 Aug 2007 & $\mathrm{~B}$ & & 3 \\
\hline $40-50 \mathrm{~mm} \mathrm{TL}$ & 20 Sep 2007 & $\mathrm{~B}$ & & 3 \\
\hline > 200 mm TL & 20 Sep 2007 & $\mathrm{~B}$ & & 3 \\
\hline \multicolumn{5}{|l|}{ Other } \\
\hline Zooplankton & 26 Jun 2007 & $\mathrm{~A}$ & Bulk $\delta^{13} \mathrm{C}$ analysis & 4 \\
\hline Zooplankton & 20 Aug 2007 & $\mathrm{~A}$ & & 6 \\
\hline $\begin{array}{l}\text { Epibenthic } \\
\text { invertebrates }\end{array}$ & 20 Aug 2007 & $\mathrm{~B}$ & & 4 \\
\hline Sediment & 20 Aug 2007 & B & & 4 \\
\hline Macroalgae & 20 Aug 2007 & B & & 4 \\
\hline
\end{tabular}

10 min hold, then 190 to $250^{\circ} \mathrm{C}$ at $8^{\circ} \mathrm{C} \mathrm{min}^{-1}$ with $5 \mathrm{~min}$ hold). An isotopically calibrated $\mathrm{CO}_{2}$ reference was introduced at the beginning and end of each GC run to convert the raw data for combusted FAME peaks into $\delta^{13} \mathrm{C}$ values according to the formula:

$$
\delta^{13} \mathrm{C}_{\text {sample }}=\left[\left({ }^{13} \mathrm{C} /{ }^{12} \mathrm{C}_{\text {sample }}-\delta^{13} \mathrm{C} /{ }^{12} \mathrm{C}_{\mathrm{PDB}}\right)-1\right] \times 1000
$$

$\delta^{13} \mathrm{C}$ values were corrected using working standards composed of several FAMEs calibrated against National Institute of Standards and Technology standard reference materials. FAME $\delta^{13} \mathrm{C}$ values were corrected for the methyl-group addition during methylation according to the formula:

$$
\delta^{13} \mathrm{C}_{\mathrm{FA}}=\left[(\mathrm{n}+1) \cdot\left(\delta^{13} \mathrm{C}_{\mathrm{FAME}}-\delta^{13} \mathrm{C}_{\mathrm{MeOH}}\right)\right] / n
$$

where $\delta^{13} \mathrm{C}_{\mathrm{FA}}$ represents the FA $\delta^{13} \mathrm{C}$ prior to methylation, $\delta^{13} \mathrm{C}_{\mathrm{FAME}}$ and $\delta^{13} \mathrm{C}_{\mathrm{MeOH}}$ are the $\delta^{13} \mathrm{C}$ values of the measured FAME and methanol used during methylation, respectively, and $n$ is the number of carbon atoms in the (non-methylated) FA. For the present study, the $\delta^{13} \mathrm{C}$ of the methanol used for FAME preparation was $-45.3 \%$. In addition to essential FAs, the FAs that presented the greatest abundance, were present in all samples and for which no coelutions occurred were studied: i.e. $14: 0,15: 016: 0,18: 0,16: 1 \omega 7,18: 2 \omega 6$,

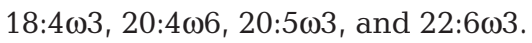

Bulk $\boldsymbol{\delta}^{\mathbf{1 3}} \mathbf{C}$ analysis. As it was not possible to meet mass requirements for $\mathrm{FA} \delta^{13} \mathrm{C}$ analysis for zooplankton and epibenthic invertebrates, $\delta^{13} \mathrm{C}$ ranges of potential food sources were estimated from bulk carbon isotope analysis. Composite samples of zooplankton ( $\mathrm{n}=10$, $>100$ ind.), benthic harpacticoids ( $\mathrm{n}=2, \sim 100$ ind.), amphipods ( $\mathrm{n}=2,10$ ind.), sediment samples and macroalgae samples (Gracilaria sp., $\mathrm{n}=2$; Ulva sp., $\mathrm{n}=2$ ) were analysed for bulk $\delta^{13} \mathrm{C}$. Zooplankton, epibenthic invertebrates, sediment and macroalgae were briefly acidified in $\mathrm{HCl}(10 \%)$ to eliminate carbonates, then rinsed with distilled water, dried $\left(60^{\circ} \mathrm{C}, 12 \mathrm{~h}\right)$ and stored at $-80^{\circ} \mathrm{C}$. Samples were homogenised and weighed into a tin capsule and combusted in a Carlo Erba NC2500 elemental analyser at the Stable Isotopes in Nature Laboratory, New Brunswick, Canada. Resultant $\mathrm{CO}_{2}$, delivered via continuous flow to a Finnigan Mat Delta Plus IRMS, was analysed for stable carbon isotopes and presented as delta values. Analytical error over the course of the study was monitored using International Atomic Energy Agency (IAEA) standards (CH6: $-10.4 \pm 0.14 \%$ o $\mathrm{SD}_{\text {; }} \mathrm{CH} 7$ : $-31.8 \pm 0.11 \%$ SD). The SD of IAEA standards per run was never $>0.23 \%$. 
Data analysis. Changes in FA composition or FA $\delta^{13} \mathrm{C}$ during settlement were explored by comparing 'settling' and 'settled' individuals (10-20 and 20-50 mm TL, respectively; see 'Results: stomach contents'). Fish $>200 \mathrm{~mm}$ TL were not taken into account for comparison, as they were not from the same cohort. Differences in FA $\delta^{13} \mathrm{C}$ between lipid classes were explored separately for 6 size classes: $10-15,15-20,20-30$, $30-40,40-50$ and $>200 \mathrm{~mm}$ TL . Significant differences were assessed by the Mann-Whitney $U$-test (XLSTATPRO 7.5, Addinsoft). Differences between bulk $\delta^{13} \mathrm{C}$ signatures of potential foods were assessed by a Kruskal-Wallis test followed by a post hoc Mann-Whitney $U$-test after Bonferroni correction (XLSTAT-PRO 7.5, Addinsoft).

\section{RESULTS}

\section{Stomach contents}

Stomach contents analysis revealed a progressive switch towards benthic food items (Fig. 2). Smaller size class (10-15 and 15-20 mm TL) individuals fed mainly on planktonic prey (notably nauplii). Despite the presence of some benthic invertebrates (small harpacticoid copepodites) in stomachs of 10-15 and 15-20 mm fish, their relative numerical abundance was low (Fig. 2). The true dietary shift occurred in the $20-30 \mathrm{~mm}$ size class, where presence of sand and detritus was first detected and benthic prey were present in all stomachs in much larger numbers than zooplankton (Fig. 2). In the $30-40$ and $40-50 \mathrm{~mm}$ size classes, the benthic omnivore/detritivore diet was confirmed, with macrophyte debris and more sand and detritus (Fig. 2). As the smaller size classes (10-15 and 15-20 mm) were planktivores, they were considered as not yet settled but in transition between sea and lagoon, and thus categorised as settling juveniles. The size classes above $20 \mathrm{~mm}$ (i.e. $20-30,30-40$ and $40-50 \mathrm{~mm}$ ) presented all the signs of benthic omnivore behaviour and were therefore categorised as settled juveniles.

\section{FA composition}

When summed, the selected FAs (14:0, 15:0, 16:0, $18: 0,16: 1 \omega 7,18: 2 \omega 6,18: 4 \omega 3,20: 4 \omega 6,20: 5 \omega 3$ and 22:6 $\omega 3$ ) represented the major part of total FA weight (63.1 to $77.8 \%$ and 67.4 to $84.8 \%$ of total FA weight for NL and PL, respectively). The most abundant FA was 16:0 in both lipid classes (Table 2). Although generally

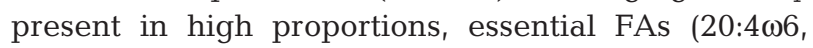
20:5 $\omega 3,22: 6 \omega 3$ ) were more abundant in PL and repre-

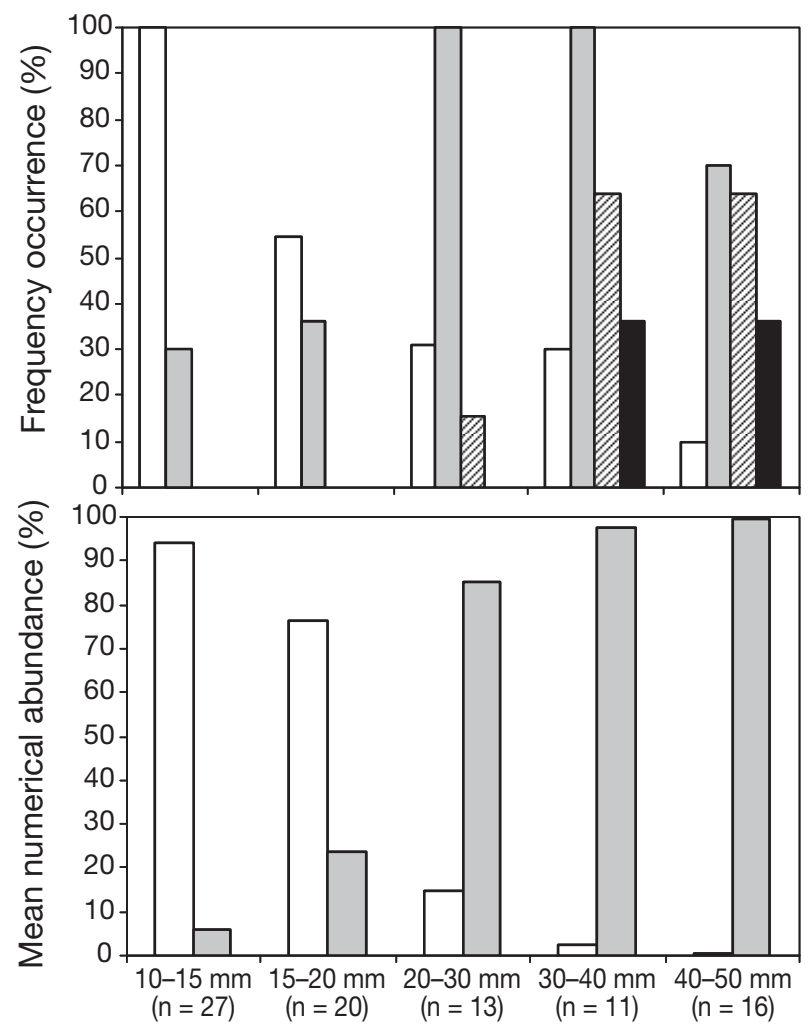

Fig. 2. Liza saliens. Stomach content analysis data. Frequency of occurrence and mean numerical abundance of prey items found in L. saliens stomachs. TL: total length. White bars: zooplankton; grey bars: epibenthic invertebrates; hatched bars: sand/detritus; black bars: macrophyte material

sented up to $36 \%$ of total FA weight for smaller size classes. Settlement significantly affected FA composition in both lipid classes: in NLs, the proportion of 14:0

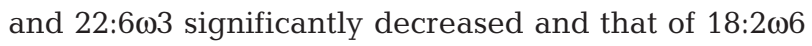
and 20:4 66 increased in settled individuals (MannWhitney $U$-test, $\mathrm{p}<0.05$; Table 2 ). In PLs, the same patterns were observed between settling and settled fish, along with a significant decrease in the proportion of 18:0 ( $p<0.05$; Table 2). The FA composition of PLs from young adult fish $(>200 \mathrm{~mm}$ ) was generally similar to that of settled fish, except for the proportions of 16:0

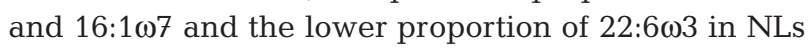
$(\mathrm{p}<0.05$; Table 2$)$.

\section{Bulk $\delta^{13} \mathrm{C}$ of potential foods}

The $\delta^{13} \mathrm{C}$ of potential Liza saliens food items varied from $-23.01 \%$ (zooplankton) to $-11.8 \%$ (benthic macroalgae) (Fig. 3). Epibenthic invertebrates and sediment had intermediate values $(-17.13$ and $18.23 \%$, respectively). Although no significant differences were found between benthic food items (e.g. epibenthic invertebrates, sediment or benthic macroalgae), all dif- 


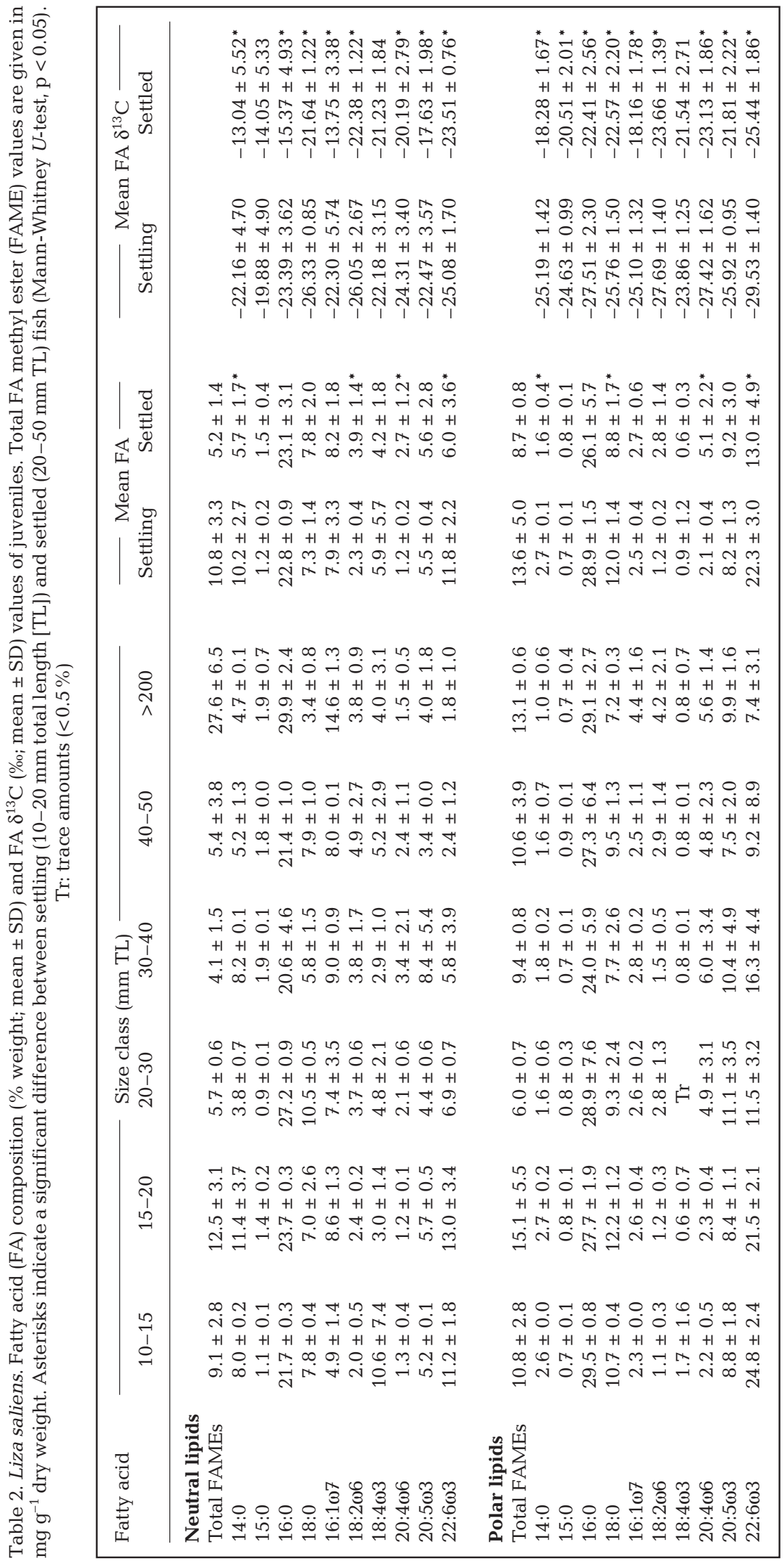

fered significantly from zooplankton (Kruskal-Wallis, p < 0.05; Fig. 3). As zooplankton sampled in June $(\mathrm{n}=4)$ did not differ significantly from that sampled in August $(\mathrm{n}=6)$ (Mann-Whitney $U$-test, $\mathrm{p}<0.05$ ), the samples were pooled (see Fig. 3).

\section{$\delta^{13} \mathrm{C}$ of individual FAs}

$\delta^{13} \mathrm{C}$ values for NL-derived FAs in 10-15 and 15-20 $\mathrm{mm}$ individuals were similar and ranged from $-20 \%$ for $15: 0$ to $-26 \%$ o for 18:2 $\omega 6$ (Fig. 4). In contrast, the $\delta^{13} \mathrm{C}$ values of $14: 0,15: 0,16: 0,16: 1 \omega 7$ and 20:5 $\omega 3$ were considerably enriched (up to 15\% increase for 14:0) in individuals from the 20-30 mm size class (Fig. 4). In the 30-40 and 40-50 $\mathrm{mm}$ size classes, these FAs had more depleted $\delta^{13} \mathrm{C}$, while remaining above the $10-15 \mathrm{~mm} \delta^{13} \mathrm{C}$ values (Fig. 4). Overall, the NL-derived FAs $14: 0,16: 0,18: 0,16: 1 \omega 7,18: 2 \omega 6,20: 4 \omega 6$ and 20:5 3 were significantly isotopically heavier in settled fish compared to the smaller settling fish (Mann-Whitney $U$-test, $\mathrm{p}<0.05$; Table 2).

PL-derived FA $\delta^{13} \mathrm{C}$ values ranged from $-24.5 \%$ for $16: 1 \omega 7$ and $18: 4 \omega 3$ to $-28.5 \%$ for $22: 6 \omega 3$ in the smaller size classes (Fig. 4). As for NL-derived FAs, $\delta^{13} \mathrm{C}$ values of individual FAs increased with size (Fig. 4). However, in contrast to NL-derived FAs, this enrichment was gradual and the most enriched $\delta^{13} \mathrm{C}$ values were observed for the 30-40 and 40-50 mm size classes (Fig. 4). The FAs that exhibited maximal relative $\delta^{13} \mathrm{C}$ increase were 14:0, 16:0, 16:1 $107,18: 2 \omega 6$ and 20:5 3 (6\% increase for 16:0 and $20: 5 \omega 3$ to $8 \%$ increase for $14: 0$ and 16:107) (Fig. 4). The other PL-derived FAs had a more limited relative $\delta^{13} \mathrm{C}$ increase, varying from $3 \%$ for $18: 0$ to $5 \%$ for 18:4 $\omega 3$. Overall, the PL-derived FAs 14:0, 16:0, 18:0, 16:1 $107,18: 2 \omega 6$,

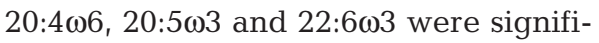
cantly isotopically heavier in settled than settling fish (Mann-Whitney $U$-test, $\mathrm{p}<0.05$; Table 2). In both lipid classes, an increase in intermolecular variability was observed for middle-sized fish (20-30 and 30-40 mm) (Fig. 5). This high variability of $16 \%$ for NL-derived 


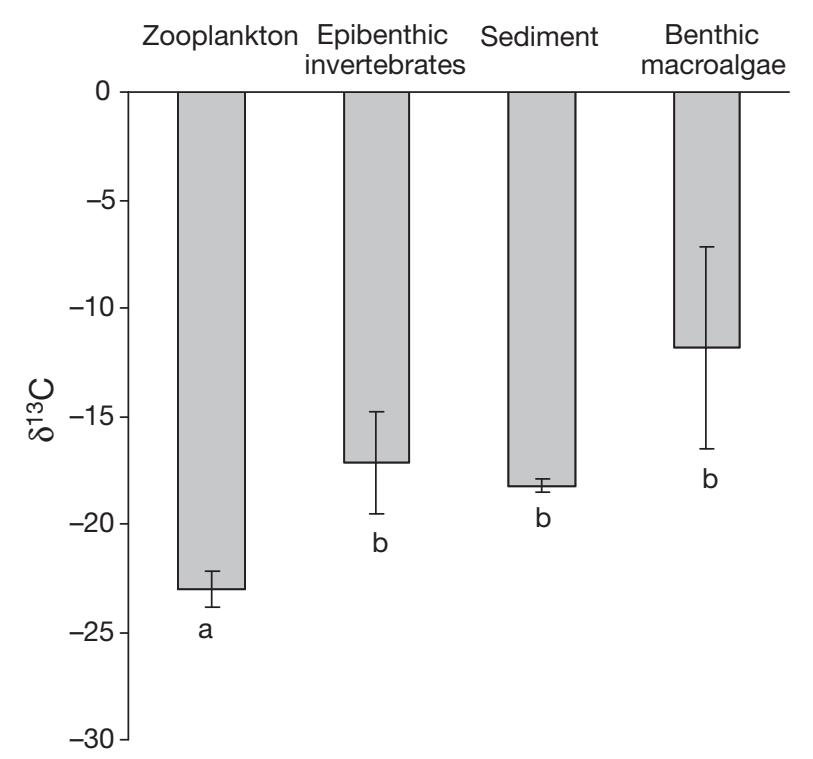

Fig. 3. Bulk $\delta^{13} \mathrm{C}$ signatures (mean $\pm \mathrm{SD}$ ) of the potential food items of Liza saliens juveniles. Zooplankton $(\mathrm{n}=10)$, epibenthic invertebrates $(n=4)$, sediment $(n=4)$, benthic macroalgae $(n=4)$. Food items with different letters are significantly different (Kruskal-Wallis test followed by a post hoc MannWhitney $U$-test, $\mathrm{p}<0.05$ )

FAs and of $8 \%$ for PL-derived FAs decreased again in larger size classes (Fig. 5). In the 10-15 and 15-20 mm size classes, NL-derived 22:6 63 was significantly heavier than that derived from PLs (Mann-Whitney $U$-test, $\mathrm{p}<0.05$; Fig. 4). This was also the case for 14:0, 15:0, $16: 0,16: 1 \omega 7,18: 2 \omega 6$ and $20: 5 \omega 3$ in the $20-30$ and 30-40 mm size classes ( $p<0.05$; Fig. 4).

\section{DISCUSSION}

\section{$\delta^{13} \mathrm{C}$ values of individual FAs}

In the smallest size class, FA $\delta^{13} \mathrm{C}$ (NL- and PLderived) ranged from -20 to $-28 \%$ (Fig. 4). These values are consistent with the bulk $\delta^{13} \mathrm{C}$ signatures of zooplankton (Fig. 3) and are typically planktonic in lagoon and coastal food webs, taking into account a slight ${ }^{13} \mathrm{C}$ depletion in lipids relative to bulk tissue (Herzka et al. 2002, Vizzini \& Mazzola 2005, 2008, Vizzini et al. 2005, Pepin \& Dower 2007). We are therefore confident that the smallest size class was representative of the marine-planktonic phase of Liza saliens juveniles. As expected, the transition towards the lagoon food web and the diet shift affected most FAs' $\delta^{13} \mathrm{C}$ values. Indeed, in comparison to their younger congeners, settled individuals displayed significant ${ }^{13} \mathrm{C}$ enrichment in most of their FAs in both lipid classes (Table 2). This enrichment coincided with the presence of benthic food items in the stomachs of $L$. saliens $>20 \mathrm{~mm}$ and is consistent with the higher $\delta^{13} \mathrm{C}$ values of benthic resources (Figs. $2 \& 3$ ). In marine environments, the $\delta^{13} \mathrm{C}$ values of benthic primary producers are more positive than those of phytoplankton (France 1995). It is believed that the reduced water turbulence in the benthos results in a thicker boundary layer around benthic algae, restricting the diffusion rate of $\mathrm{CO}_{2}$ or $\mathrm{HCO}_{3}{ }^{-}$, with subsequent reduced discrimination against ${ }^{13} \mathrm{C}$ (France 1995). In coastal environments, this phenomenon may generate a mean $\delta^{13} \mathrm{C}$ enrichment of $5 \%$ or more in benthic algae (including epiphytes) relative to phytoplankton (France 1995, Herzka et al. 2002, Jaschinski et al. 2008, Vinagre et al. 2008). However, the plankton-like FA $\delta^{13} \mathrm{C}$ values of $>200 \mathrm{~mm}$ fish were quite surprising, and suggested that young adult L. saliens, which are supposed to have a similar diet to settled juveniles, occupy a distinct isotopic niche. Although considered as benthic omnivores/detritivores, it has been shown that in eutrophic systems grey mullet species can behave as efficient zooplanktivorous pump-filters, foraging simultaneously on plankton and benthos (Cardona et al. 2001). This does not seem to have been the case here, as their FA composition was quite similar to that of settled fish, which forage exclusively in benthos (Table 2). Another possible explanation could be a strong reliance on planktonic microalgae, as shown for another grey mullet species Liza ramada in the Mira estuary (Almeida 2003). Although the lack of stomach contents analysis in young adult $L$. saliens in the present study precluded any firm conclusion as to dietary niche, the very low intermolecular $\delta^{13} \mathrm{C}$ variability between FAs and lipid classes justifies their use as reference for stabilised diet (Figs. 4 \& 5).

The change in diet of the $20-30 \mathrm{~mm}$ specimens was accompanied by an increase in intermolecular $\delta^{13} \mathrm{C}$ variability between FAs from 4 and $7 \%$ (in PLs and NLs, respectively) for individuals in the 10-15 mm size class to 8 and $16 \%$ (in PLs and NLs, respectively) for individuals in the 20-30 and 30-40 mm size classes (Fig. 5). This dramatic increase might reflect the greater variability of food sources exploited by fish in a transitional state between planktonic and benthic resources. In the 40-50 and > $200 \mathrm{~mm}$ size classes, intermolecular $\delta^{13} \mathrm{C}$ variability was low, in agreement with progressive diet stabilisation (Fig. 5). The great intermolecular variability was due to the fact that ${ }^{13} \mathrm{C}$ enrichment during settlement was not equally great for all FAs (Table 2). The most enriched FAs were 14:0, 15:0, 16:0, 16:1 $\omega 7$ and 20:5 $\omega 3$, and the $\delta^{13} \mathrm{C}$ differences between settling and settled fish lay within those expected between plankton and benthos (Table 2, Fig. 3).

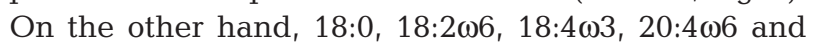
22:6 13 displayed only moderate enrichment (Table 2).

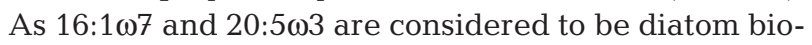




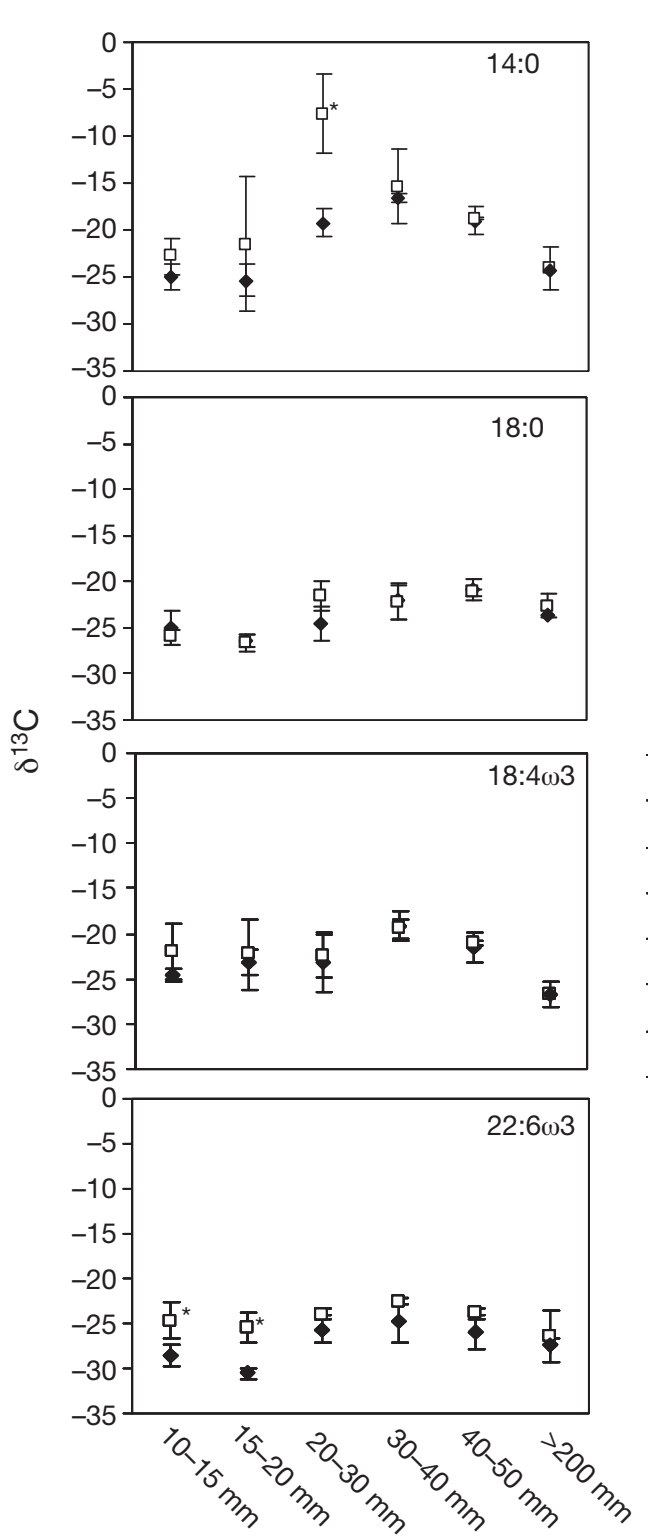

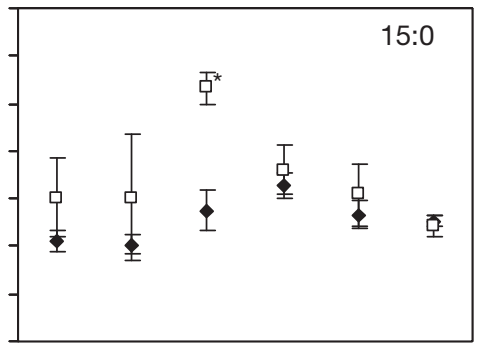
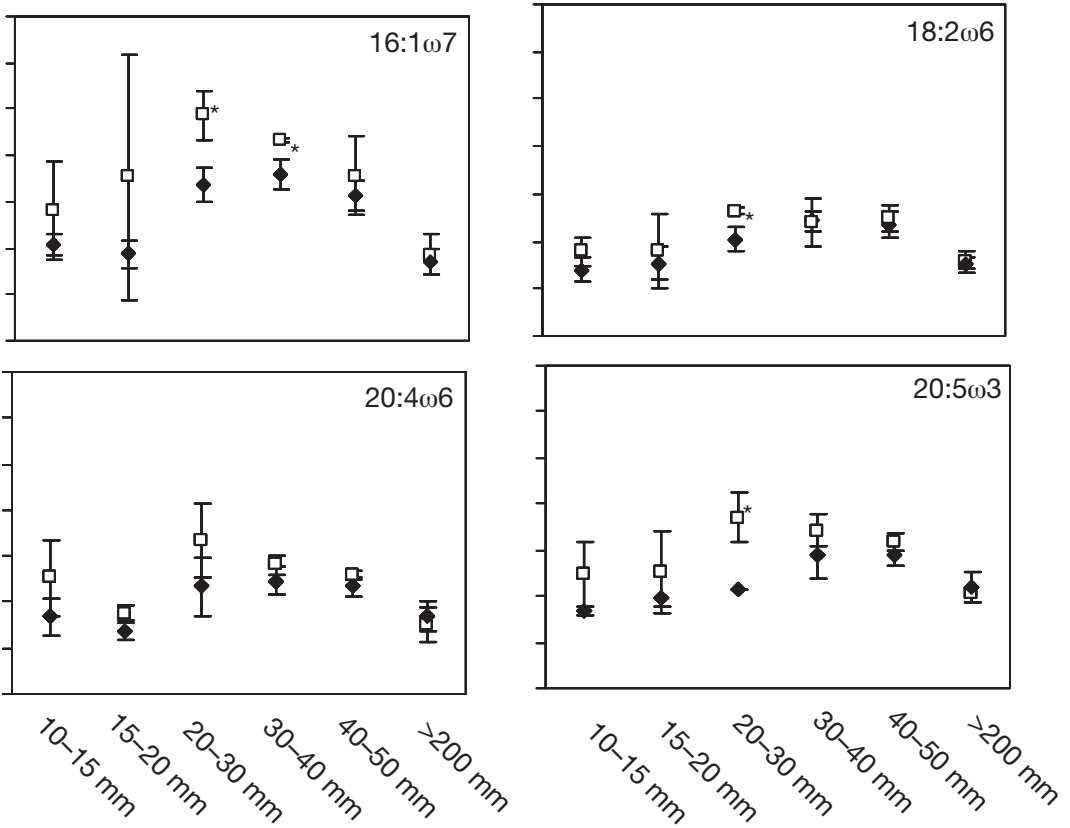

Fig. 4. Liza saliens. $\delta^{13} \mathrm{C}$ signatures (mean $\pm \mathrm{SD}$ ) of individual fatty acids within neutral lipids $(\square)$ and polar lipids $(\bullet)$ of juveniles $(n=3) .{ }^{*}$ Significant difference between lipid classes for the given size class (Mann-Whitney $U$-test, $\mathrm{p}<0.05)$. TL: total length

markers and 14:0 and 16:0 are abundant in algal taxa in general (Viso \& Marty 1993, St. John \& Lund 1996, Dalsgaard et al. 2003), it is likely that the increase in $\delta^{13} \mathrm{C}$ in settled fish reflects increased reliance on epiphytic or benthic diatoms. Moreover, 15:0 is often used as a bacterial biomarker (Bec et al. 2003, Dalsgaard et al. 2003, Jaschinski et al. 2008), and its enriched $\delta^{13} \mathrm{C}$ values suggest the benthic origin of the bacterial carbon on which settled fish rely, probably by ingesting sediment directly. The particularly high mean $\delta^{13} \mathrm{C}$ values of $14: 0,15: 0,16: 0$ and $16: 1 \omega 7$ in the $20-30 \mathrm{~mm}$ fish $(-7.6$ to $-10.9 \%$ or $14: 0$ and $16: 0$, respectively, in NLs) were close to the bulk $\delta^{13} \mathrm{C}$ values of macroalgae (Table 2, Fig. 3). The latter might reflect a momentary reliance on macroalgae. If this is the case, this reliance would concern only the $20-30 \mathrm{~mm}$ size class, as in 30-40 and 40-50 mm fish, FA $\delta^{13} \mathrm{C}$ decreased again towards values closer to that of bulk sediment (Figs. 3 $\& 4)$. On the other hand, the other FAs $(18: 0,18: 2 \omega 6$,

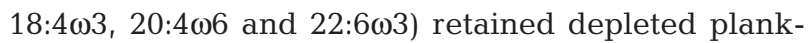
ton-like signatures in all size classes, suggesting that the sources of some FAs remained partially or totally planktonic even for fish that adopted benthic foraging habits (Fig. 4). This was the case of 22:603, for which $\delta^{13} \mathrm{C}$ values remained low ( -23 and $-25 \%$ for NLs and PLs, respectively) even in larger settled fish (Table 2, Fig. 4). The dramatic size-linked decrease in the proportion of this FA in NLs and PLs (Table 2) indicates that, in contrast to other essential FAs $(20: 4 \omega 6,20: 5 \omega 3)$, the benthic resources exploited by Liza saliens juveniles could not provide them with sufficient amounts of

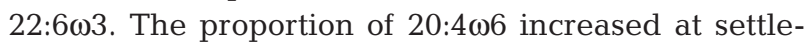




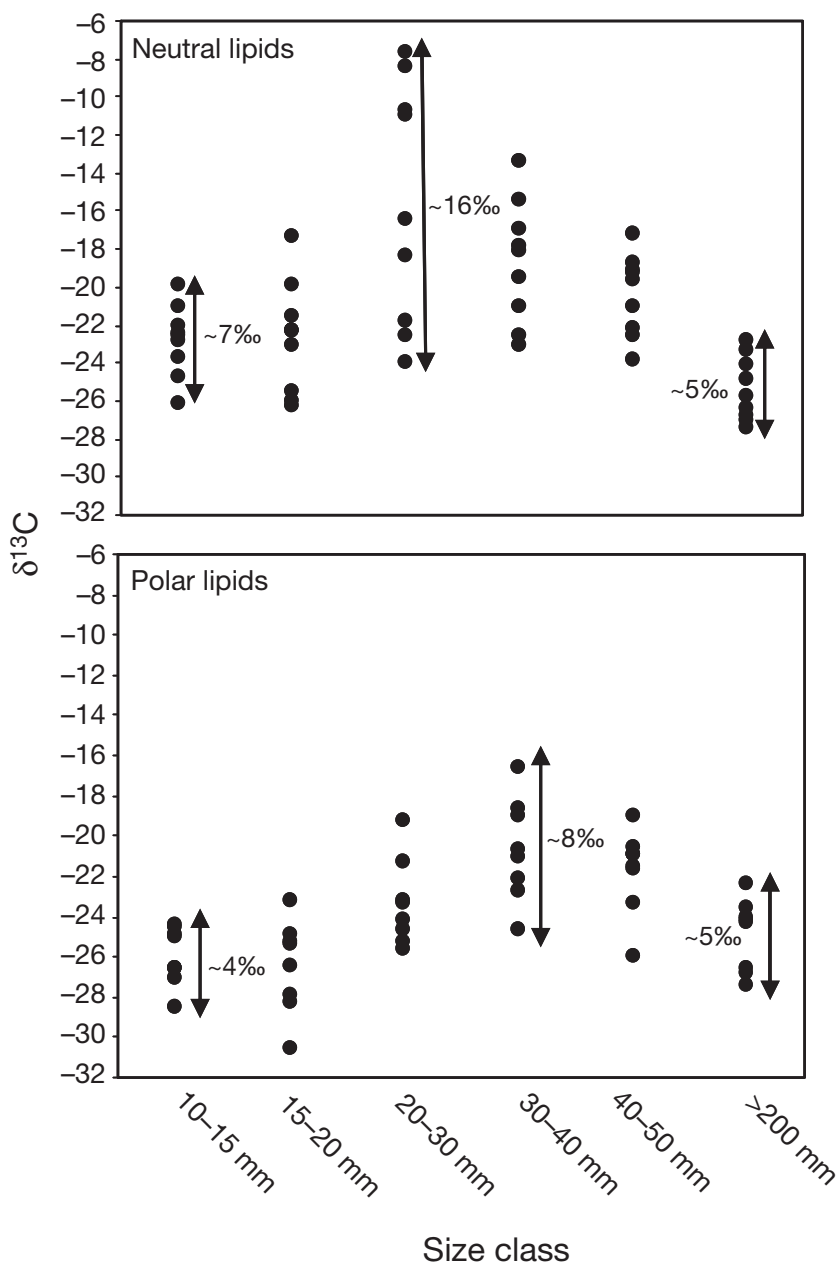

Fig. 5. Liza saliens. Intermolecular $\delta^{13} \mathrm{C}(\%)$ variability between fatty acids within lipid classes of juveniles. Each dot is the mean value $(\mathrm{n}=3)$ for one of the 10 studied fatty acids

ment and that of 20:5 $\omega 3$ remained unchanged in both lipid classes (Table 2, Fig. 4). This indicates that these 2 essential FAs are more abundant than 22:6 13 in settled individuals' food. Moreover, the increase in the intermolecular $\delta^{13} \mathrm{C}$ variability of the essential FAs in the settled size classes compared to $10-15 \mathrm{~mm}$ fish indicates isotopically distinct sources for these components (Fig. 5). It appears that in the Vassova Lagoon, the main sources of 22:6 $\omega 3$ are ${ }^{13} \mathrm{C}$-depleted and thus more planktonic, whereas those of 20:5 $\omega 3$ are more ${ }^{13} \mathrm{C}$-enriched and closer to the $\delta^{13} \mathrm{C}$ values expected for the

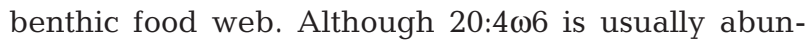
dant in red algae such as Gracilaria sp. (Kayama et al. 1989, Fleurence et al. 1994), which were abundant in the lagoon, it does not have a macroalgal $\delta^{13} \mathrm{C}$ signature (Figs. $3 \& 4$ ), but seems to be of mixed planktonic and benthic origin. Therefore, even after settlement, $L$. saliens juveniles must still be relying on plankton to obtain certain essential dietary components.

\section{Lipid class $\delta^{13} \mathrm{C}$ differences}

For marine fish, PLs are the building blocks of the cell membranes and NLs (mainly triacylglycerols) are the main form of energy storage (Ackman 1980, 1989, Sargent et al. 1993). In order to satisfy their energy needs, most fish mobilise NLs before PLs (Sargent et al. 1989). On the other hand, juvenile fish are in a period of intense growth and need PLs to build new tissues. It is consequently more likely that newly synthesised PLs are simply added to those already present in tissue, rather than replacing them. Therefore, while PLs tend to maintain a stable FA composition in order to maintain the structural integrity of cells, NLs undergo intense turnover due to constant energy demands and dietary input (Sargent et al. 1989, Dalsgaard et al. 2003). Thus, because of the contrasting physiological roles of NLs and PLs, NLs should integrate dietary FA $\delta^{13} \mathrm{C}$ signatures more quickly than PLs. In the case of a $\delta^{13} \mathrm{C}$ change in dietary FAs due to diet shift or movement between distinct food webs, the different integration rates of the 2 lipid classes should generate a temporary imbalance between $\delta^{13} \mathrm{C}$ as measured for PL- and NL-derived FAs. The present results show that, for the size classes for which dietary transition was expected (e.g. from sea to lagoon, or plankton to benthos), the ${ }^{12} \mathrm{C} /{ }^{13} \mathrm{C}$ ratio of some FAs differed between NLs and PLs (Fig. 4). In the 10-15 and 15-20 mm size classes, which are considered to have recently entered the lagoon, most FAs in NLs tended to be slightly enriched in ${ }^{13} \mathrm{C}$ compared to FAs in PLs, and for 22:6 63 the difference was statistically significant (Fig. 4). At this size (10-20 mm), Liza saliens are still feeding on planktonic organisms (Fig. 2). However, the contrasting environmental parameters of the lagoon as compared to the open sea could lead to a more ${ }^{13} \mathrm{C}$-enriched signal in lagoon zooplankton compared to its marine counterpart. Consequently, the NLderived FAs of the young L. saliens that recently entered the lagoon should be representative of their new ${ }^{13} \mathrm{C}$-enriched lagoon zooplanktonic prey, whereas PL-derived FAs should maintain the lighter isotopic signal characteristic of their previous marine food. In 20-30 $\mathrm{mm}$ fish, the $\delta^{13} \mathrm{C}$ imbalance between NL- and PL-derived 22:6 13 disappeared, and other more pronounced $\delta^{13} \mathrm{C}$ discrepancies between NLs and PLs

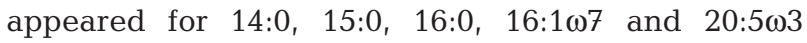
(Fig. 4). In this size class, L. saliens begins to forage on benthos, which is more enriched in ${ }^{13} \mathrm{C}$ than plankton (Fig. 3). Again, NLs appeared to integrate this isotopic change in diet faster than PLs, which probably showed values intermediate between planktonic and benthic food. These $\delta^{13} \mathrm{C}$ imbalances should disappear after feeding on an isotopically constant diet for a period long enough to allow PLs to fully integrate the $\delta^{13} \mathrm{C}$ 
dietary signal. Indeed, the $\delta^{13} \mathrm{C}$ discrepancy between lipid classes disappeared in larger juveniles and adults that are assumed to be settled and to have a stable diet (Fig. 4).

\section{CONCLUSIONS}

CSIA showed that the migration and settlement of Liza saliens in their lagoon nursery were followed by changes in the origin of dietary carbon. By coupling isotope analysis to FA biomarkers, it was possible to determine that the dietary carbon shift was due to increased reliance on benthic diatoms and bacteria. It was also demonstrated that benthic and planktonic foods are not qualitatively equivalent and that L. saliens juveniles relied on plankton for their 22:6 $\omega 3$ input even after they started foraging in the benthos. Strong evidence also emerged that PLs integrate the dietary $\delta^{13} \mathrm{C}$ signal slower than NLs, and that a recent isotopic dietary change generates discrepancies between the $\delta^{13} \mathrm{C}$ values of the FAs derived from the 2 lipid classes. The information obtained from FA $\delta^{13} \mathrm{C}$ signals, which cannot be provided by bulk tissue isotope analysis, may be valuable in conservation biology, as it enables deeper understanding of the nutritional function of nursery areas and feeding grounds in general. Moreover, the differential FA $\delta^{13} \mathrm{C}$ turnover between lipid classes observed for $L$. saliens could be used with aquatic organisms sharing similar lipid dynamics as an indicator of recent dietary switch or recent migration between isotopically distinct areas or food webs, and could provide a unique opportunity to obtain simultaneous information on recent and earlier diet history.

Acknowledgements. We thank K. Kademoglou for her help with stomach contents analysis, the staff of the Fisheries Cooperative of Nestos Lagoons and FRI of Nea Peramos and Y. Van den Berg for precious help with field collection. We also thank the 4 anonymous reviewers, who provided useful comments and helped improve the manuscript.

\section{LITERATURE CITED}

Ackman RG (1980) Fish lipids. In: Connell JJ (ed) Advances in fish science and technology. Fishing News Books, Farnham, p 86-103

Ackman RG (1989) Marine biogenic lipids, fats and oils, Vol 1. CRC Press, Boca Raton, FL, p 1-314

Adams M (1998) Ecological role of lipids in the health and success of fish populations. In: Arts MT, Wainman BC (eds) Lipids in freshwater ecosystems. Springer-Verlag, New York, p 132-153

Albertini-Berhaut J (1980) Biologie des stades juveniles de Mugilidae dans la région marseillaise: croissance, régime alimentaire et activités enzymatiques digestives. $\mathrm{PhD}$ thesis, Université d'Aix-Marseille II
Albon SD, Langvatn R (1992) Plant phenology and the benefits of migration in a temperate ungulate. Oikos 65: $502-513$

Alfaro AC, Thomas F, Sergent L, Duxbury M (2006) Identification of trophic interactions within an estuarine food web (northern New Zealand) using fatty acid biomarkers and stable isotopes. Estuar Coast Shelf Sci 70:271-286

Almeida PR (2003) Feeding ecology of Liza ramada (Risso, 1810) (Pisces, Mugilidae) in a south-western estuary of Portugal. Estuar Coast Shelf Sci 57:313-323

Arts MT (1998) Lipids in freshwater zooplankton: selected ecological and physiological aspects. In: Arts MT, Wainman BC (eds) Lipids in freshwater ecosystems. SpringerVerlag, New York, p 71-86

Arts MT, Ackman RG, Holub BG (2001) Essential fatty acids in aquatic ecosystems: a crucial link between diet and human health and evolution. Can J Fish Aquat Sci 58: $122-137$

Bec A, Desvilettes C, Véra A, Fontvieille D, Bourdier G (2003) Nutritional value of different food sources for the benthic Daphnidae Simocephalus vetulus: role of fatty acids. Arch Hydrobiol 156:145-163

Bec A, Martin-Creuzburg D, Von Elert E (2006) Trophic upgrading of autotrophic picoplankton by the heterotrophic nanoflagellate Paraphysomonas sp. Limnol Oceanogr 51: 1699-1707

Bell G, Sargent J (1996) Lipid nutrition and fish recruitment. Mar Ecol Prog Ser 134:315-316

- Cardona L, Royo P, Torras X (2001) Effects of leaping grey mullet Liza saliens (Osteichthyes, Mugilidae) in the macrophyte beds of oligohaline Mediterranean coastal lagoons. Hydrobiologia 462:233-240

Chamberlain PM, Bull DI, Black HIJ, Ineson P, Evershed RP (2004) Lipid content and carbon assimilation in Collembola: implications for the use of compound-specific carbon isotope analysis in animal dietary studies. Oecologia 139: 325-335

Christie WW (1982) Lipid analysis, 2nd edn. Pergamon Press, Oxford

Dalsgaard J, St. John M, Kattner G, Müller-Navarra D, Hagen W (2003) Fatty acid trophic markers in the pelagic marine environment. Adv Mar Biol 46:225-230

Desvilettes C, Bec A (2009) Formation and transfer of fatty acids in aquatic microbial food webs: role of heterotrophic protists. In: Arts MT, Brett MT, Kainz M (eds) Lipids in aquatic ecosystems. Springer, New York, p 25-42

> Dini ML, Carpenter SR (1992) Fish predators, food availability and diel vertical migration in Daphnia. J Plankton Res 14: 359-377

> Fleurence J, Gutbier G, Mabeau S, Leray C (1994) Fatty-acids from 11 marine macroalgae of the French Brittany coast. J Appl Phycol 6:527-532

Folch J, Lees M, Sloane-Stanley GH (1957) A simple method for the isolation and purification of total lipids from animal tissues. J Biol Chem 226:497-509

France RL (1995) Carbon-13 enrichment in benthic compared to planktonic algae: foodweb implications. Mar Ecol Prog Ser 124:307-312

Gibson RN (1994) Impact of habitat quality and quantity on the recruitment of juvenile flatfishes. Neth J Sea Res 32: 191-206

> Herzka SZ, Holt SA, Holt GJ (2002) Characterization of settlement patterns of red drum Sciaenops ocellatus larvae to estuarine nursery habitat: a stable isotope approach. Mar Ecol Prog Ser 226:143-156

> Jaschinski S, Brepohl DC, Sommer U (2008) Carbon sources and trophic structure in an eelgrass Zostera marina bed, 
based on stable isotope and fatty acid analyses. Mar Ecol Prog Ser 358:103-114

Kayama M, Araki S, Sato S, Imbs AB (1989) Lipids of marine plants. In: Ackman RG (ed) Marine biogenic lipids, fats, and oils, Vol 2. CRC Press, Boca Raton, FL, p 3-48

Kjerfve B (1994) Coastal lagoon processes. Elsevier Science Publishers, Amsterdam

Koussoroplis AM, Lemarchand C, Bec A, Desvilettes C and others (2008) From aquatic to terrestrial food webs: decrease of the docosahexaenoic acid/linoleic acid ratio. Lipids 43:461-466

Koutrakis ET (1994) Biology and population dynamics of grey mullets (Pisces: Mugilidae) in the Lake Vistonis and the lagoon of Porto-Lagos. PhD thesis, Aristotle University of Thessaloniki

Koutrakis ET (2004) Temporal occurrence and size distribution of grey mullet juveniles (Pisces, Mugilidae) in the estuarine systems of the Strymonikos Gulf (Greece). J Appl Ichthyol 20:76-78

Koutrakis ET, Tsikliras AC, Sinis AI (2005) Temporal variability of the icthyofauna in a Northern Aegean coastal lagoon (Greece). Influence of environmental factors. Hydrobiologia 543:245-257

Lau DCP, Leung KMY, Dudgeon D (2009) Evidence of rapid shifts in the trophic base of lotic predators using experimental dietary manipulations and assimilation-based analyses. Oecologia 159:767-776

McConnaughey T, McRoy C (1979) Food-web structure and the fractionation of carbon isotopes in the Bering Sea. Mar Biol 53:257-262

Meier-Augenstein W (2002) Stable isotope analysis of fatty acids by gas chromatography-isotope ratio mass spectrometry. Anal Chim Acta 465:63-79

Murphy DE, Abrajano TA (1994) Carbon isotope compositions of fatty acids in mussels from Newfoundland estuaries. Estuar Coast Shelf Sci 39:261-272

Napolitano GE (1998) Fatty acids as trophic and chemical markers in freshwater ecosystems. In: Arts MT, Wainman BC (eds) Lipids in freshwater ecosystems. SpringerVerlag, New York, p 21-44

Olsen Y (1998) Lipids and essential fatty acids in aquatic food webs. In: Arts MT, Wainman BC (eds) Lipids in freshwater ecosystems. Springer-Verlag, New York, p 161-202

Orfanidis S, Stamatis N, Ragias V, Schramm W (2005) Eutrophication patterns in an eastern Mediterranean coastal lagoons: Vassova, Delta Nestos, Macedonia, Greece. Mediterr Mar Sci 6:17-30

> Pepin P, Dower J (2007) Variability of the trophic position of larval fish in a coastal pelagic ecosystem based on stable isotope analysis. J Plankton Res 29:727-737

Perga ME, Gerdeaux D (2005) 'Are fish what they eat' all year round? Oecologia 144:598-606

Pond D, Dixon D, Bell M, Fallick A, Sargent J (1997a) Occurrence of 16:2(n-4) and 18:2(n-4) fatty acids in the lipids of the hydrothermal vent shrimps Rimicaris exoculata and Alvinocaris markensis: nutritional and trophic implications. Mar Ecol Prog Ser 156:167-174

Pond DW, Segonzac M, Bell MV, Dixon DR, Fallick AE, Sargent JR (1997b) Lipid and lipid carbon stable isotope composition of the hydrothermal vent shrimp Mirocaris fortunata: evidence for nutritional dependence on photosynthetically fixed carbon. Mar Ecol Prog Ser 157: 221-231

Editorial responsibility: Ivan Nagelkerken, Nijmegen, Netherlands
Richoux N, Froneman P (2008) Trophic ecology of dominant zooplankton and macrofauna in a temperate, oligotrophic South African estuary: a fatty acid approach. Mar Ecol Prog Ser 357:121-137

> Rieley G, Dover CLV, Hedrick DB, Eglinton G (1999) Trophic ecology of Rimicaris exoculata: a combined lipid abundance/stable isotope approach. Mar Biol 133:495-499

Rittenhouse TAG, Semlitsch RD, Thompson FR (2009) Survival costs associated with wood frog breeding migrations: effects of timber harvest and drought. Ecology 90: 1620-1630

Sargent J, Henderson RJ, Tocher DR (1989) The lipids. In: Halver JE (ed) Fish nutrition. Academic Press, San Diego, CA, p 153-218

Sargent JR, Bell JG, Bell MV, Henderson RJ, Tocher DR (1993) The metabolism of phospholipids and polyunsaturated fatty acids in fish. In: Lahlou B, Vitiello P (eds) Aquaculture: fundamental and applied research. American Geophysical Union, Washington, DC, p 103-124

St. John MA, Lund T (1996) Lipid biomarkers: linking the utilization of frontal plankton biomass to enhanced condition of juvenile North Sea cod. Mar Ecol Prog Ser 131:75-85

Tsihrintzis VA, Sylaios GK, Sidiropoulou M, Koutrakis ET (2007) Hydrodynamic modeling and management alternatives in a Mediterranean, fishery exploited, coastal lagoon. Aquacult Eng 36:310-324

Van den Meersche K, Van Rijswijk P, Soetaert K, Middelburg J (2009) Autochthonous and allochthonous contributions to mesozooplankton diet in a tidal river and estuary: integrating carbon isotope and fatty acid constraints. Limnol Oceanogr 54:62-74

- Vander Zanden MJ, Casselman JM, Rasmussen JB (1999) Stable isotope evidence for the food web consequences of species invasions in lakes. Nature 401:464-467

Vanni MJ, Lampert W (1992) Food quality effects on lifehistory traits and fitness in the generalist herbivore Daphnia. Oecologia 92:48-57

Veefkind RJ (1997) Carbon isotope ratios and composition of fatty acids: tags and trophic markers in pelagic organisms. PhD thesis, Utrecht University

- Vinagre C, Salgado J, Costa MJ, Cabral HN (2008) Nursery fidelity, food web interactions and primary sources of nutrition of the juveniles of Solea solea and S. senegalensis in the Tagus estuary (Portugal): a stable isotope approach. Estuar Coast Shelf Sci 76:255-264

> Viso AC, Marty JC (1993) Fatty acids from 28 marine microalgae. Phytochemistry 34:1521-1533

Vizzini S, Mazzola A (2005) Feeding ecology of the sand smelt Atherina boyeri (Risso 1810) (Osteichthyes, Atherinidae) in the western Mediterranean: evidence for spatial variability based on stable carbon and nitrogen isotopes. Environ Biol Fishes 72:259-266

Vizzini S, Mazzola A (2008) The fate of organic matter sources in coastal environments: a comparison of three Mediterranean lagoons. Hydrobiologia 611:67-79

Vizzini S, Savona B, Do Chi T, Mazzola A (2005) Spatial variability of stable carbon and nitrogen isotope ratios in a Mediterranean coastal lagoon. Hydrobiologia 550: 73-82

Wysujack K, Greenberg LA, Bergman E, Olsson IC (2009) The role of the environment in partial migration: food availability affects the adoption of a migratory tactic in brown trout Salmo trutta. Ecol Freshw Fish 18:52-59

Submitted: July 31, 2009; Accepted: January 8, 2010

Proofs received from author(s): March 19, 2010 